\title{
Rise of right-wing populism in the Europe of today - outlines of a socio- theoretical exploration ${ }^{1}$
}

\author{
Hans-Jürgen Bieling (hans-juergen.bieling@uni-tuebingen.de) \\ Eberhard Karls Universität Tübingen, Germany
}

This article addresses the political economic and socio-cultural causes and driving forces of today's right-wing populism. For this end, it draws on the concept of the "double movement" developed by the Hungarian-Canadian economic historian Karl Polanyi to explore the rise of fascism in the interwar period. The constitutive elements of the "double movement" at that time were the dialectics of two organisational principles, i.e. economic liberalism and social protection. Also today, such a "double movement" is recognisable. The processes of globalisation and financialisation that are induced by market-liberal dis-embedding generate a variety of forms of social exclusion and socio-cultural identity crises which in turn stimulate processes of social resistance and protection. However, with a view to today's constellation, further socio-structural and political-strategic explanatory components have to be taken into account beyond the perspective of the "double movement".

Keywords: Europe, Social Movements, Democracy, Social Policy, Social Structures

\section{Introduction}

Right-wing populist movements and parties have experienced enormous popularity for some time now. Their ascent came about in several waves (Priester 2012). The first wave already began in the early 1970s. Supported by the Progress Parties in Denmark and Norway, the Swiss People's Party (SVP), the Front National in France (FN) and the Vlaams Belang in Belgium, their agenda was primarily directed against the existing forms of a fairly comprehensive, centralized welfare state. The second wave in the 1990s took up this criticism - such as the Lega Nord in Italy - but at the same time increasingly turned against the deepening of European integration implemented by the Maastricht Treaty and against the concepts of a multicultural society. For most of the parties - the UKIP in Great Britain, the Sweden Democrats, the (True) Finns, and not least the programmatically reoriented Freedom Party of Austria (FPÖ) - ethno-nationalist to openly racist positions increasingly came to the fore. This also applies to the third wave, i.e. Lijst Pim Fortuyn (LPF), founded in the early 2000s, and, since 2006, the Partij voor de Vrijheid (PVV) in the Netherlands led by Geert Wilders, the Polish Party Prawo i Sprawiedliwość (PIS), as well as other party foundations such as the MoVimento 5 Stelle (M5S) in Italy or Alternative für Deutschland (AfD).

${ }^{1}$ An earlier, German version of this paper has been published in WSI-Mitteilungen 8/2017. 
The third wave is also characterized by the fact that right-wing populist forces have increasingly turned their programmatic orientation to social problems and insecurities. They seemed to have rediscovered the social question (Dörre, 2016; Becker, 2017). They increasingly (Müller, 2016; Klein, 2016) influence politics by having an impact on political discourses - on the euro crisis, the crisis of the European migration regime or the problems of the multicultural society - and by exerting pressure on established decision-makers, i.e. indirectly affecting their political agenda. In addition, as a result of parliamentary election successes and sometimes landslide changes in majority relations, they are involved in forming government as a tolerating, cooperating or even leading force - for example in Italy (Lega), Austria (FPÖ), Denmark (DPP 2001-2011), Switzerland (SVP), Poland (PIS) or Hungary (Fidesz). Even in countries where majority voting makes it difficult for right-wing populist parties to rise - such as in France (Front National) or Great Britain (UKIP) - they directly influence important political decisions in the context of presidential elections or referendums.

The article, however, does not focus on the far-reaching European and socio-political consequences of the course set - such as the Brexit or the management of the Eurozone crisis and the crisis of the migration regime - but rather on the social (political-economic and socio-cultural) causes and drivers of today's right-wing populism. It is a matter of assessing how profound the change is and which processes potentially counteract it. In particular, the paper reflects to what extent the concept of the "double movement" of economic liberalism and social protection developed by Karl Polanyi (1977 [1944]) with a view to the catastrophe of the 1930s and 1940s is instructive in order to understand the rise of rightwing populism. In the following, it is argued that a "double movement" is definitely recognisable. The processes of globalisation and financialisation that are induced by market liberal dis-embedding generate a variety of forms of social exclusion and socio-cultural identity crises, which in turn stimulate processes of social resistance and social protection. Since the right-wing populist reactions unfold neither everywhere nor uniformly and differ considerably from the developments in the 1930s, it is necessary to take further explanatory components into account: firstly, a structural component that takes a closer look at historically specific political-economic constellation; and secondly, a political-strategic component that explicitly turns to the field of discursive and political conflicts.

\section{Polanyi's conceptualisation of the "double movement"}

Historical comparisons tend to be rather daring and often produce questionable results. If Karl Polanyi's considerations in the study "The Great Transformation" are used here, this should not be read as a comparative analogy. Too great are the differences to the fascist movements in the inter-war period (Berman, 2016), too serious are the qualitative changes that have taken place since then in the structures and the mode of operation of capitalism, its socio-economic, socio-cultural and political-institutional constitution. Looking back at Polanyi, taking into account the qualitative differences, the focus is less on the concrete phenomena and forms of the "double movement" than on some structural connections and mechanisms of action that can claim a certain explanatory and interpretive power even under strongly changed conditions.

\subsection{The conflicting organisational principles}

The reconstruction of European crisis history carried out by Polanyi is based on a "pendulum theory" (Silver, 2003, 16ff). That means that he discusses social development as a tension between two conflicting organisational principles:

The one was the principle of economic liberalism, aiming at the establishment of a self-regulating market, relying on the support of the trading classes, and using largely laissez-faire and free trade as its methods; the other was the principle of social 
protection aiming at the conservation of man and nature as well as productive organization, relying on the varying support of those most immediately affected by the deleterious action of the market - primarily, but not exclusively, the working and the landed classes - and using protective legislation, restrictive associations, and other instruments of intervention as its methods. (Polanyi 1957 [1944], 132)

For Polanyi, the development of these two organisational principles is by no means balanced in capitalism. Although the economic-liberal conception of the self-regulating market is a fiction or a myth - markets are always socially, culturally, legally and institutionally embedded - it is politically very powerful. Under capitalist conditions, it is structurally privileged, as it were, and puts the patterns of social organisation under considerable pressure to adapt and to reorganize. The politically generated de-embedding of the economy, that is, the detachment of the market system from society, corresponds with tendencies of commodification. These tendencies cause social and cultural crises (Saval, 2016) and are particularly problematic for the fictitious commodities that were not primarily created for sale - for Polanyi (1957 [1944], 72ff), these are labour, land and money. In the course of the comprehensive transformation of work and everyday life, the traditional ways of life, social ties and values of different social classes are often called into question. In addition to the problems of impoverishment and social inequality, Polanyi particularly points to the socio-cultural distortions, not least the experiences of injustice and disregard articulated politically by those affected and their organisations.

As long as these needs are taken into account through corrective state interventions - for example in the field of financial relations - and labour and social policy concessions, i.e. the establishment and implementation of certain social protection rights and measures of de-commodification, the double movement remains asymmetrical, but will not develop any social explosive force. This actually only happens when tensions in the market system increase and become more acute in the context of conflicting power-political (class) strategies:

(...) when tensions between the social classes developed, society itself was endangered by the fact that the contending parties were making government and business, state and industry, respectively, their strongholds. Two vital functions of society, the political and the economic, were being used and abused as weapons in a struggle for sectional interests. It was out of such a perilous deadlock that in the twentieth century the fascist crisis sprang. (Polanyi, 1957 [1944], 133f)

This addition is important and revealing in two ways: on the one hand, Polanyi makes it clear that the double movement does not unfold as an abstract logic. On the contrary, its concrete course is shaped by the respective historical constellation and the power relations and political (class) conflicts inscribed in it. On the other hand, these conflicts and thus also the forms of the double movement cannot be derived directly from the social problems, but are subject to complex processes of cultural interpretation and discursive mediation (Polanyi, 1957 [1944], 158ff).

\subsection{Material and cultural conflict dimensions}

According to Polanyi, in order to grasp the political dynamics or explosive force of labour and social policy controversies, it is necessary to turn to what Edward P. Thompson (1980) later referred to as the "moral economy". This sphere forms an important component of social embedding, but in the form of a constitutively effective, permanent, social conflictdriven shaping of the economy through "dynamic combinations of norms, meanings and practices" (Palomera \& Vetta 2016, 414). The moral economy encompasses the norms and obligations modernized under capitalist conditions, hence not only the socio-economic relations, but also the socio-cultural processes of the production of meaning. It does not 
represent a normative, but an analytical conception. The core values and priorities of the moral economy are subject to the influences of competing forces and social milieus, and can therefore be specifically defined and emotionally boiled up by the populist right.

The perspective developed by Polanyi makes it possible to include class-specific interests and conflicts in the analysis, without too closely linking the development of (new) political orientations to class relations as an expression of social inequalities; this is especially so since inequalities other than class - especially those in terms of gender, ethnic groups, geographical areas, or age groups - also influence relations and conflicts of material distribution (Bieling, 2012). But even if distributional conflicts are conceptualized in a more complex way, it remains unclear how material inequalities in social structures - within and between different social groups - are experienced, perceived and interpreted. Or put positively: Polanyi already addresses the socio-theoretically disputed question of the relationship between social distribution and cultural conflicts of justice or recognition, including the latter underlying experiences of social disregard, very early on and with foresight (Honneth, 1992; Fraser, 1995). His remarks go beyond the analytical separation of socio-economic and socio-cultural processes, which is only partially productive. Instead he focuses on the question of how social inequalities - mediated by concrete everyday experiences articulate themselves in the arenas of cultural production of meaning and politics.

Under the conditions of serious crises or exceptional situations, the relationship between objective and perceived social problems and political action is often contingent. Contrary to their supposed socioeconomic interests, insecure social groups in extreme constellations, driven by a desire for social protection, often tend to join nationalistic political programs and alliances that undermine the foundations of inclusive social solidarity (Zick et al., 2011; Gidron \& Hall, 2017). Insofar as new solidarity structures emerge in such situation, these are usually very narrowly and exclusively defined, and often even - underpinned by racist ideologies or concepts of national superiority - aggressively turn to the outside world. Polanyi $(1979,98 \mathrm{f})$ attributes the attractiveness of the nationalistic, sometimes fascist course, among other things, to the fact that it can rely on anti-individualist discourses, directed against both bourgeois and socialist individualism, without having to fundamentally revolutionize social power relations.

As inspiring and meritorious the concepts developed by Polanyi, including the historicalempirical illustrations, may be, some analytical limits should not be ignored. For the context considered here, it is especially relevant that the "double movement" is conceptualised as a kind of pendulum between the principle of the self-regulating market and the principle of social protection, which opens up only an insufficient view of the qualitative changes in capitalist production relations (Silver, 2003, 16ff). Insofar as Polanyi explores the central features of the specific historical constellation - for the 19th century the system of balance of power, the international gold standard, the self-regulating market, and the liberal state - he does not systematically relate these features to the dynamics of capitalist accumulation. Their reach and depth - for example in the form of internal or external capitalist conquest or penetration ("Landnahme") - has changed several times with regard to capitalist production structures, labour relations or modes of living. In addition to the socio-structural dynamics of development, also the question of their political-strategic processing, and thus the particular features of the political field, is not really explored by Polanyi. He often turns to everyday experiences and the socio-cultural processes of meaning production guided by them, but not systematically addresses the political-strategic struggles, that is, the public debates and conflicts between competing political organisations. 


\section{The double movement in Europe today}

In the following explanation of the rise of right-wing populist movements and parties, both kinds of weakness or omission are to be absorbed and mitigated: by including the special political-economic quality, in which the principle of the self-regulating market asserts itself; and also by including the programmatic-strategic profiling of political movements as moments of the right-wing populist activation of social protection needs in the concept of the double movement.

\subsection{The new quality of capitalist penetration}

With respect to the first aspect - the particular quality of the effectiveness of the selfregulatory market - not only the forms of economic cooperation and exchange but also social production relations have undergone an extensive and profound transformation in recent decades; at least, if one assumes with Robert W. Cox $(1989,39)$ a comprehensive understanding of production that also includes the production of knowledge and social relations as well as the moral concepts and institutional conditions that have an impact on the production of physical goods. Thus, the forms and patterns of political-economic and socio-cultural embedding - and dis-embedding - of production and reproduction have repeatedly changed in history. These changes can not least be attributed to the dynamics of capitalist development. The latter represents an enormous expansive force, as it is characterised by the endeavour of capital to continually open up new, profitable investment spheres and to reorganise these by means of new technologies and market processes.

Moreover, not only the priorities and patterns of capitalist accumulation, but also the social struggles and forms of resistance inscribed in it have repeatedly changed in history. In retrospect, following Kees van der Pijl $(1998,36 \mathrm{ff})$, three constellations can ideal-typically be distinguished:

The first constellation - to which Polanyi's remarks on the 18th and 19th centuries refer was primarily marked by "original" or "primitive" accumulation. Living labour was formally subsumed under capital, so that the process of proletarisation progressed. Many social groups - formerly self-employed craftsmen, farmers or even the previously economically inactive population (many women and children) - were torn out of traditional social relationships and subjected to a previously unknown and unfamiliar control regime. Not infrequently, this new kind of capitalist heteronomy, especially in the process of its establishment, was characterized by considerable potential for violence.

In the second constellation - from the end of the 19th to the beginning of the 20th century - the real subordination of labour to capital moved to the centre of capitalist development, meaning a permanent increase in labour productivity and relative added value. As a result, the forms of production and work organisation changed continuously; social struggles more and more shifted into the factories. The workers' resistance to the increasing concentration of labour was relatively successful in the era of Fordism. Supported by increased trade union bargaining power, many societies succeeded in establishing a social regulatory "compromise balance" and in enforcing certain wage, labour, and social protection zones as well as minimum standards.

The third constellation refers to the globalisation-induced tendencies of dis-embedding (Altvater \& Mahnkopf, 1999). It is characterized on the one hand by the emergence of global financial relations and value chains, but on the other hand also by the fact that capitalist penetration is accompanied by an expansion of service work and is increasingly concentrated on the reproductive sphere. The search for productive resources and investment spheres leads to a comprehensive (re-)commodification of social conditions. Attention is now focused on optimizing the general discipline and availability of the labour force in terms of professional qualifications, family circumstances, housing and eating habits, health and leisure (Voss \& Pongratz, 1998). In the form of a "neue Landnahme" (Dörre, 
2009), politically supported by legal, administrative and institutional reforms, many areas of everyday life are incorporated into the process of capitalist valorisation and exploitation. At the same time, new forms of resistance are emerging in response to these tendencies - such as the privatisation of public infrastructure or pensions, a further intensification of work, or the commercialisation of everyday life.

The specific dynamics of the constellations listed here cannot - in view of a certain concurrence and overlapping - be empirically separated from each other in the strict sense. Nevertheless, the last-mentioned constellation points to the fact that the dis-embedding of the economy, forced by market-liberalism, is throwing the social structure of European societies into confusion. In this vortex there are also numerous winners, especially among the property owners. More conspicuous, however, is the fact that social upward mobility, which was characteristic of the post-war decades, has weakened, come to a halt or even reversed. The expansion of atypical, often precarious employment relationships has stimulated new fears of social decline within upper labour and middle classes as a result of which the moral norms of solidarity of social groups are shaken and sometimes fundamentally transformed. Due to the sociocultural mediation, i.e. the complex struggles over the creation of meaning, this process of transformation does not present itself unambiguously, and unfolds in different social milieus in quite different ways (Koppetsch, 2018; Gidron \& Hall, 2017). Oliver Nachtwey $(2016,167)$ explains for the middle classes:

The status fears of the middle-classes sometimes lead to economist interpretations, to negative classification and to the disregard of weaker groups [...]. The centre of society partly renounces solidarity with weaker strata, by setting itself apart, ensuring one's own well-being. Where before a certain liberality prevailed, it know gives way to more rigorous ideas about morality, culture and ways of living.

And relevant sections of the working class are also increasingly attracted to nationalistpopulist positions. As Didier Eribon $(2016,130)$ illustrates with the example of France and the rise of the Front National, this reorientation also reflects material uncertainties and emergencies, the processing of which can be very different:

It depends entirely on how the everyday experience in question is structured, whether, for example, practical solidarity predominates in the workplace or fear of competition for one's own job, whether one feels part of the informal parents' network of a school or desperate about the daily difficulties in a 'problem neighbourhood', etc.

It is therefore crucial for the success of nationalist populism that social conditions are perceived as unfair. In general, the increased fears about the future - as a result of the financial crisis and the crisis of the European regime of migration - and repeated experiences of loss of control, perspective, or tradition (Detje et al., 2017) in connection with social disregard ensure that feelings of anger accumulate, which in turn seek political forms of articulation. In many countries the socialist and communist parties had long assumed this function. For some time, however, they have no longer been able to fulfil their role as mouthpieces and identity-forming powers. The reasons for this vary. For many, the communist parties - especially after the collapse of real socialism - appear to be dogmatically frozen and incapable of action. The situation is somewhat different for the socialist and social democratic parties. After the first two waves of revisionism - the acceptance of representative democracy after the First World War and the arrangement with capitalism tamed by the welfare state after the Second World War - in a further wave of revisionism in the 1990s in search of a "third way" between neo-liberalism and big government, they had approached many positions of economic liberalism (Sassoon, 1997, 730ff). This reinforced the impression that the social needs and views of relevant sections of employees are hardly noticed by the public anymore (D'Eramo, 2013, 15ff). 


\subsection{The role of European integration}

Through the process of European integration, the problem constellation described here has been indirectly but systematically promoted. Thus, the new quality of capitalist penetration is closely linked to the integration thrust since the 1980s. Through the implementation of several integration projects - the European Monetary System (EMS), the EC Single Market Project, the Economic and Monetary Union, the eastward enlargement of the EU, and the Lisbon Strategy - a highly integrated economic area has developed. The deepened integration of production and market relations generates internal dynamics of competitive deregulation and liberalisation. Notwithstanding some flanking labour, social, and structural policy instruments, the scope for action of the welfare state, i.e. distributional and intervention policy, has been structurally curtailed.

In recent decades, economic liberalism has favoured the genesis of European financial market capitalism, i.e. the generalisation of various forms of financialisation favors (Bieling, 2013; Nölke, 2016). These are reflected, among other things, in a reorganisation of companies geared to financial markets, including appropriate investment and management strategies. In addition, pension systems, public infrastructure organisation and real estate markets are increasingly subjected to the rationality of financial markets and the interests of financial assets owners. Both dynamics - the change in management and business concepts, as well as the reorganisation of the welfare state and the public sector promote social inequality and often impair the quality of employment. For example, the proportion of atypical, often precarious forms of employment has increased almost continuously as a result of the pressure of competition and deregulation exerted by the integration process (Schulze Buschoff, 2016).

The cross-border pressure of competition and deregulation, which in some respect is driven by the financial markets, is being perpetuated by European integration in the form of a "new constitutionalism" (Gill, 1998, 5), which establishes the primacy of private property rights, freedoms for investors and forms of market discipline while at the same time tending to isolate the related policy from democratic control. Specifically, there are numerous legal - contractual law and secondary legislation - decisions, specific institutional arrangements and - often quite elitist - networks of policy negotiation. When Marco D'Eramo $(2013,23 \mathrm{ff})$ speaks of a "new oligarchic order," he alludes to precisely this reciprocal conditionality of the oligarchical or financial-capitalist nature and institutionally autonomous political negotiations, while at the same time aspirations of democratic control and influence are refused. The legitimation of such structures follows in part a functional logic that considers the processes of market and competition integration as tending to be depoliticized, but also in part to a realistic logic that regards a comprehensive European design of the economy as too complicated and politically unenforceable. In addition, the course of European integration over the past decades also seems to be oriented towards a superordinate model that can be described as (neo-)liberal-cosmopolitan. The neo-liberal component focuses on individual - economic and political - protection and freedom rights, while the cosmopolitan component insists on transferring the cross-border realisation of individual rights - especially those of economic actors - to supranational organisations. In the words of Peter Gowan (2001, 79f):

The new liberal cosmopolitanism [...] seeks to overcome the limits of national sovereignty by constructing a global order that wants to govern the political as well as economic aspects of both the internal and external behaviour of states. This is not a conception advocating any world government. Rather, it proposes a set of disciplinary regimes [...] reaching deep into the economic, social and political life of the states subject to it, while safeguarding international flows of finance and trade. 
At the centre of (neo-)liberal cosmopolitanism are above all economic objectives. However, it would fall short to reduce the cosmopolitan orientation to such objectives alone. Especially for the EU, the removal not only of economic but also cultural, ethnic, religious or institutional and legal discrimination - such as obstacles to freedom of movement within the EU - play a prominent role. In addition, the EU is opposed to state repression and assaults on individual liberties and is therefore anxious to strengthen forms of constitutional organisation and individual legal claims - from freedom of expression to social rights.

The (neo-)liberal-cosmopolitan self-image of the EU has been severely shaken by the crisis processes of recent years: on the one hand, because neo-liberal concepts have contributed to the financial, economic and Eurozone crisis and the crisis management focused on austerity and competitiveness further aggravated the economic and social crisis; on the other hand, because the crisis of the European migration regime has drawn attention to the fact that the transition to a multicultural society was only weakly underpinned by social integration and instead accompanied by many social and cultural conflicts. These have been increasingly broken up in the various social arenas in recent years and have become the subject of public debates and disputes.

\subsection{The European crisis dynamics as a window of opportunity: programmatic profiles and reorientation of right-wing populist parties}

It is not unusual that political parties - at least for those who are not in government publicly address social problems and crisis phenomena, and even to scandalize them. Such practices only become unusual and in need of explanation when they are particularly successful and cause significant changes in the political situation. Some interpretations attribute the success of populist forces to the specific practices of political staging in mass media (Wodak, 2015). However, the question of why such strategies are successful and why apart from the post-fascist societies of Southern Europe - populations are currently reached less by left-wing than by right-wing populist parties through public discourses is not answered in this way.

In the academic discussion on the formation of political parties, two concepts are offered in response to this question. The concept of the "representation gap" is based on the assumption that the established parties in government tend to move to the centre in the fields of economic and social policy as well as in terms of culture (Decker, 2015, 28). As a result, corresponding representation gaps would emerge at the political margins - in the case of right-wing populism on the right-wing side of the political arena - which would then be filled by the establishment of new parties and movements (Patzelt, 2015, 19). In contrast, the conception of new cleavages refers to sustainable structural changes in society (Bieling, 2018, 493ff). Originally, the cleavage theory developed by Seymour Martin Lipset and Stein Rokkan (1967) referred to four cleavages - between capital and labour, between church and state, between city and country, and between centre and periphery. Since the 1970s, attempts have been made to identify new cleavages: culturally, for example, between materialists and post-materialists (Inglehardt, 1977) or between libertarian and authoritarian orientations (Kitschelt, 1997); and materially between the winners and losers of modernisation or globalisation (Kriesi et al., 2008).

More recently, a new cleavage is sometimes conceived as an opposition between cosmopolitan and communitarian preferences (Zürn \& de Wilde, 2016). Looking at the strategic and programmatic orientations of the established political forces on the one hand and the populist right on the other, many aspects seem to align quite well along this opposition. More specifically, however, in some regards the cleavage should be defined more precisely: first, by emphasising the specific (neo-)liberal quality of cosmopolitanism as a force partially undermining the nation state, above all the institutions responsible for social 
cohesion (Gowan, 2001); and secondly, by emphasising that the central points of reference of the aspirations of community identity formation are the nation and the nation state. In view of the developments and social crisis processes outlined above, the argument can be brought forward that right-wing populist parties and movements articulate a new cleavage between (neo-)liberal cosmopolitanism and ethnonationalist identities. This conflict is driven by the new quality of the first component of the double movement, i.e. the processes of increased social inequality, uncertainty and disregard induced by globalisation, deregulation and privatisation. Against these tendencies right-wing populist forces are now increasingly taking the principle of social protection into account. In doing so, they imagine, irrespective of the progress of globalisation and European integration, a comprehensive national sovereignty and capacity to act. The nationalist orientation is combined with a series of specific discourses and political positions. Beyond all national peculiarities, the following main points can be identified:

First, the ethno-nationalist orientations propagated by most right-wing populist parties and movements are based on an ethnopluralist or cultural-racist worldview (Eckert, 2010). Cultural racism assumes a structural incompatibility of cultures defined in an essentialist fashion. According to the motto: others "are just like that" and we defend our own national core culture, the predominant foils of interpretation and attributions of characteristics and behaviours generate a "second skin" that the ethnically defined group members are supposedly unable to remove.

Secondly, this worldview is condensed in an increasing EU scepticism (Werner, 2013). As explained above, the (neo)liberal-cosmopolitan orientation of the EU generates social conflicts, as a result of which European integration - under the influence of right-wing populism - becomes nationalistically politicised. Thus, in the euro crisis, national economic problems - especially with regard to the crisis-ridden periphery - have often been portrayed as natural and therefore inevitable in order to conclude the impossibility of a functioning common currency or at least to subject one's own membership to a referendum; and in the crisis of the European border regime, actually all populist parties have demanded a strict limitation and control regime with regard to non-EU immigrants, and some - for example, the Front National, the Lega Nord, the PVV, the FPÖ or the Finns - even the renunciation of Schengen, i.e. the reintroduction of EU internal border controls.

In contrast to their clearly neo-liberal economic programmes of the 1980s and 1990s, a third discursive focus of right-wing populism is the linking of the national and the social question (Dörre, 2016). In Germany, this link is still very coarsely presented when, for example, Björn Höcke (speaker of the AfD in the state Thuringia and most prominent representative of the radical right "Flügel" within the party) talks about the fact that the new social question does not address the distribution relations between upper and lower social classes, but between those inside and outside the nation state. However, apart from such statements, the Alternative for Germany (AfD) generally tried to keep issues of social and economic policy in the background - to avoid conflicts resulting from the heterogeneous economic orientations among their social base. Much clearer and more systematic is the linking of the social and national question in programmatically matured right-wing populist parties that try to distinguish themselves in the area of social policy, such as the Front National, the Finns, the Polish PiS, or the Hungarian Fidesz (Becker, 2017). In the mobilisation of nationalist solidarity, these parties increasingly present themselves as defenders of an ethnically focused welfare state that intervenes to protect the national economy and the well-being of families. It is not uncommon that selective protectionist economic and trade policies - for example public criticism and rejection of TTIP - accompany such social policy programmes.

A fourth central point of reference - the criticism of the European migration regime and the ethno-nationalist orientations already point in this direction - is the rejection of the 
multiculturalist model of society. This model is mostly seen as an expression of "foreign domination", as a symbol of a loss of national identity, and at the same time as a source of crime and moral decay. In return, the right-wing populist parties not only advocate the strengthening of a national core culture, but at the same time pursue the dismantling of constitutional procedures and the establishment of authoritarian and discriminatory forms of government (Becker, 2017).

Fifth, the right-wing populist parties propagate an anti-Muslim discourse, which - with the exception of the Dutch PVV - is often accompanied by anti-feminist and homophobic components (Mayer et al., 2014). Some observers go so far as to suggest that these unifying elements have already displaced the anti-Semitism of the traditional extreme right (Hafez, 2014). If one takes a closer look at party-internal controversies of the right-wing populists, however, it can rather be assumed that the anti-Semitic elements lose influence due to the negative impact on the public, but in many cases persist and are only superimposed by Islamophobia.

\section{Outlook: nationalist populism as a challenge to democracy}

This article was based on the question of whether and to what extent the rise of right-wing populism can be explored with the help of the concept of the double movement developed by Karl Polanyi. It has been shown that this conception is quite instructive in the understanding of right-wing populism. It draws attention to the social and cultural uncertainties and experiences of injustice and disregard caused by the market-liberal restructuring of the economy and society. Such developments in turn generate indignation and feelings of rage, which are increasingly interpreted in right-wing populist manner. Although the concept of the double movement - concerning the special quality of capitalist penetration, the modes of dis-embedding associated with it, and the specific dynamics in the political sphere of action - reaches certain explanatory limits, the argument is viable that the rightwing populism of today is to be generally understood as a Polanyian type of movement. This is all the more so since the right-wing populist parties - in contrast to the 1980s and 1990s - have in the meantime often turned to the social question and the mobilisation of nationalistically exclusive solidarities (Kuisma \& Ryner, 2014; Goodliffe, 2016). In general, they seem to succeed in significantly expanding their own voter base through welfare state and protectionist discourse elements.

The dynamics outlined above are worrying in several respects: firstly, because the permanent breaking of taboos and the mobilisation of resentment happens at the expense of minorities and constitutional guarantees such as freedom of opinion, science and the press, or independence the judiciary; secondly, because in most countries large sections of the workforce and many union members are also integrated into the right-wing populist countermovement; and thirdly, because in the confrontation with right-wing populism the discursive cleavage between (neo-)liberal cosmopolitanism and ethno-nationalist identities outlined above seems to be reproduced. In fact, both poles of the discourse have an exclusionary effect in different ways: (neo-)liberal cosmopolitanism is structurally socially exclusionary by intensifying market-mediated competitive pressures and by advancing the dismantling of collective social rights. The nationalist identities promoted by right-wing populists may, in the eyes of many, also be useful for the defence of welfare state achievements, but at the same time turn against the claims of migrants as well as ethnic and other minorities. One consequence of the new discursive cleavage is that integrative political options based on inclusionary solidarity find it difficult to gain public attention.

From the point of view of all socially and democratically oriented forces, however, it is precisely this constellation of discourses that must be broken up and overcome. On the one hand, this can be achieved by developing political projects in the national and European context - for example, in the fields of monetary, economic and financial policy, but 
also industrial policy, labour market policy and social policy - which are integrative and based on solidary and appear attractive to large population groups. This would also signal to the socially disadvantaged classes that the existing social and cultural insecurities and feelings of disregard are taken seriously, as it were the real problems serving as crystallization points for the highly fictionalized discourses of right wing populism. On the other hand, the ideological resentment and exclusion practices of right-wing populist forces must at the same time be clearly marked and rejected. This includes revealing the imaginary nature of the right-wing revolt, not least the illusionary expectation of being able to politically re-embed and democratically control the processes of globalisation at the national level alone.

\section{References}

Altvater, E., \& Mahnkopf, B., (1999). Grenzen der Globalisierung. Ökonomie, Ökologie und Politik in der Weltgesellschaft. Münster: Westfälisches Dampfboot.

Becker, J., (2017). Rechtsregierungen in Ungarn und Polen: zwischen Neoliberalismus und Nationalkonservatismus. Politikum, 3(1), 52-60.

Berman, S., (2016). Populism Is Not Fascism. Foreign Affairs, 95(6), 39-44.

Bieling, H-J., (2012). Transnationale (Krisen-)Dynamiken des Finanzmarktkapitalismus Klassenverhältnisse, Gender und Ethnizität aus politökonomischer Perspektive. Berliner Zeitschrift für Soziologie, 22(1), 53-77.

Bieling, H.-J., (2013). European Financial Capitalism and the Politics of (De-)financialization. Competition \& Change, 17(3), 283-298.

Bieling, H.-J., (2018). Die „Krise der Politik“ als Ausdruck gesellschaftlicher Kräfteverschiebungen und neuer Konfliktlinien. Das Argument, 60(4), 492-501.

Cox, R. W., (1989). Production, the State, and Change in World Order. In E.-O. Czempiel \& J. N. Rosenau (Eds.), Global Changes and Theoretical Challenges. Approaches to World Politics for the 1990s. Toronto: Lexington Books. 37-50.

Decker, F., (2015). AfP, Pegida und die Verschiebung der parteipolitischen Mitte. Aus Politik und Zeitgeschichte, 65(40), 27-32.

Detje, R., Dörre, K., Kronauer, M., \& Schumann, M., (2017). Zeitenwende oder: Zeit für eine Wende der Linken. Blätter für deutsche und internationale Politik, 62(4), 97-103

D’Eramo, M., (2014). Populism and the new Oligarchy. New Left Review, II/82, 5-28.

Dörre, K., (2009). Die neue Landnahme. Dynamiken und Grenzen des Finanzmarktkapitalismus. In: K. Dörre, S. Lessenich \& H. Rosa, Soziologie - Kapitalismus - Kritik. Eine Debatte. Frankfurt a.M.: Suhrkamp. 21-86.

Dörre, K., (2016). Die national-soziale Gefahr. Verteilungskonflikte und die Neue Rechte in Europa - sechs Thesen. Widerspruch, 35(2), 165-176. 
Eckert, R., (2010). Kulturelle Homogenität und aggressive Intoleranz. Eine Kritik der Neuen Rechten. Aus Politik und Zeitgeschichte, 60(44), 26-33.

Eribon, D., (2016). Rückkehr nach Reims. Frankfurt a.M.: Suhrkamp.

Fraser, N., (1995). From Redistribution to Recognition? Dilemmas of Justice in a „post-Socialist" Age. New Left Review, 1/212, 68-93.

Gidron, N., \& Hall, P.A., (2017). The Politics of Social Status: Economic and Cultural Roots oft he Populist Right. The British Journal of Sociology, 68(1), 57-84.

Gill, S., (1998). European Governance and New Constitutionalism: Economic and Monetary Union and Alternatives to Disciplinary Neoliberalism in Europe. New Political Economy, $3(1), 5-26$.

Goodliffe, G., (2016). From Political Fringe to Political Mainstream: The Front National and the 2014 Municipal Elections in France. French Politics, Culture \& Society, 34(3), 126-147. Gowan, P., (2001). Neoliberal Cosmopolitism. New Left Review, II/11, 79-93.

Honneth, A., (1992). Kampf um Anerkennung. Zur moralischen Grammatik sozialer Konflikte. Frankfurt a.M.: Suhrkamp.

Inglehart, R., (1977). The Silent Revolution. Changing Values and Political Styles Among Western Publics. Princeton: Princeton University Press.

Klein, J., (2016). Europapopulismus - ein genuines Phänomen im europäischen Krisenkontext? Integration, 39(4), 283-303.

Koppetsch, C., (2018): Rechtspopulismus als Klassenkampf? Soziale Deklassierung und politische Mobilisierung. WSI-Mitteilungen, 71(5), 382-391.

Kriesi, H., (2014). The Populist Challenge. West European Politics, 37(2), 361-378.

Kriesi, H., Grande, E., Lachat, R., Dolezal, M., Bornschier S., \& Frey, T., (2008). West European politics in the age of globalization. Six countries compared. Cambridge: Cambridge University Press.

Kuisma, M., \& Ryner, M., (2012). Third Way Decomposition and the Rightward Shift in Finnish and Swedish Politics. Contemporary Politics, 18(3), 325-342.

Lipset, S., \& Rokkan, S., (1967). Party Systems and Voter Alignments. Cross-National Perspectives. New York: Free Press.

Mayer, S., Ajanovic, E., \& Sauer, B., (2014). Intersections and Inconsistencies. Framing Gender in Right-Wing Populist Discourses in Austria. NORA-Nordic Journal of Feminist and Gender Research, 22(4), 250-266.

Müller, J. W., (2016). Was ist Populismus? Ein Essay. Frankfurt a.M.: Suhrkamp.

Nachtwey, O., (2016). Die Abstiegsgesellschaft. Über das Aufbegehren in der regressiven Moderne. Frankfurt a.M.: Suhrkamp. 
Nölke, A., (2016). Finanzialisierung als Kernproblem eines sozialen Europas. WSIMitteilunge,. 69(1), 41-48.

Patzelt, W. J., (2015). Die Sorgen der Leute ernst nehmen!. Aus Politik und Zeitgeschichte, 65(40), 17-21.

Palomera, J., \& Vetta, T., (2016). Moral economy: Rethinking a radical concept. Anthropological Theory, 16(4), 413-432.

Polanyi, K., (1957) [1944]. The Great Transformation. The political and economic origins of our time. Boston: Beacon Press.

Polanyi, K., (1979). Ökonomie und Gesellschaft. Frankfurt a.M.: Suhrkamp.

Priester, K., (2012). Wesensmerkmale des Populismus. Aus Politik und Zeitgeschichte, 62(5/6), 3-9.

Sassoon, D., (1997). One Hundred Years of Socialism. The West European Left in the Twentieth Century. London: Fontana Press.

Saval, N., (2016). Polanyi in our times. The Nation, December, 19-26.

Schulze Buschoff, K., (2016). Atypische Beschäftigung in Europa. Herausforderungen für die Alterssicherung und die gewerkschaftliche Interessenvertretung. Study Nr. 1, März 2016. Düsseldorf: HBS.

Silver, B. J., (2003). Forces of Labour. Worker's Movements and Globalization since 1870. Cambridge: Cambridge University Press.

Thompson, E. P., (1980). Die „moralische Ökonomie“ der englischen Unterschichten im 18. Jahrhundert. In E. P. Thompson, Plebejische Kultur und moralische Ökonomie. Frankfurt a.M.: Ullstein. 66-129.

Van der Pijl, K., (1998). Transnational Classes and International Relations. London; New York: Routledge.

Voß, G. G., \& Pongratz, H. J., (1998). Der Arbeitskraftunternehmer. Eine neue Grundform der Ware Arbeitskraft?. Kölner Zeitschrift für Soziologie und Sozialpsychologie, 50(1), 131158.

Werner, A., (2013). Rechtspopulistische Opposition in der Eurokrise. Das Argument, $55(1 / 2), 240-250$.

Wodak, R., (2015). The politics of fear. What right-wing populist discourses mean. London: Sage.

Zick, A., Küpper, B., \& Hövermann, A., (2011). Die Abwertung der Anderen. Eine europäische Zustandsbeschreibung zu Intoleranz, Vorurteilen und Diskriminierung. Bonn: FES. 
Zürn, M., \& de Wilde, P., (2016). Debating globalization: cosmopolitanism and communitarianism as political ideologies. Journal of Political Ideologies, 21(3), 280-301. 